\title{
Present Status of Fish Disease Management in Freshwater Aquaculture in India: State-of- the-Art-Review
}

\section{Mishra SS ${ }^{1 *}$, Rakesh $\mathrm{D}^{1}$, Dhiman $\mathbf{M}^{2}$, Choudhary $\mathrm{P}^{1}$, Debbar- ma $\mathrm{J}^{1}$, Sahoo SN 1 , Barua $\mathrm{A}^{1}$, Giri BS ${ }^{3}$, Ramesh $\mathrm{R}^{3}$, Ananda $\mathrm{K}^{4}$, Mishra CK $^{5}$ and Swain $\mathrm{P}^{1}$}

${ }^{1}$ Fish Health Management Division, ICAR-Central Institute of Freshwater Aquaculture (CIFA), Kausalyaganga, Bhubaneswar, Odisha, India

${ }^{2}$ Department of Zoology, Mahatma Gandhi Chitrakoot Gramodaya Vishwavidyalaya, Chitrakoot, Satna, Madhya Pradesh, India

${ }^{3}$ Regional Centre of ICAR-Central Institute of Freshwater Aquaculture, Poranki, Vijayawada, Andhra Pradesh, India

${ }^{4}$ Regional Centre of ICAR-Central Institute of Freshwater Aquaculture, Hessarghatta, Bangalore, Karnataka, India

${ }^{5}$ Regional Centre of ICAR-Central Institute of Freshwater Aquaculture, Anand, Gujarat, India

\begin{abstract}
Indian fisheries and aquaculture is an important sector of food production, providing nutritional security to the food basket, contributing to the agricultural exports and engaging about fourteen million people in different activities. With diverse aquatic resources the country has shown continuous and sustained increments in fish production since independence. Constituting about $6.3 \%$ of the global fish production, the sector contributes to $1.1 \%$ of the GDP and $5.15 \%$ of the agricultural GDP. The total fish production of 10.07 million metric tonnes, presently has nearly $65 \%$ contribution from the inland sector and nearly the same from culture fisheries. However, occurrence of disease has become a primary constraint to sustainable aquaculture production and product trade, there by affecting the socioeconomic status of fishers in country like India. Different stress factors such as inadequate physicochemical and microbial quality of culture water, poor nutritional status and high stocking density can cause infection by opportunistic pathogens. Acute level of pollutants and suspended solids can directly bring about abnormalities and mortalities in seed fishes and adults. Different opportunistic bacterial pathogens and parasites cause devastating loss to fish industry in terms of high morbidity and mortality, diminishing growth and enhanced expenditure on use of chemicals as preventive and control measures. As is understood, prevention of fish diseases assumes paramount importance in terms of sustainable growth of aquaculture
\end{abstract}

*Corresponding author: Mishra SS, Fish Health Management Division, ICARCentral Institute of Freshwater Aquaculture (CIFA), Kausalyaganga, Bhubaneswar, Odisha, India, Tel: +91 7894281261; E-mail: ss_mishra60@yahoo.co.uk

Citation: Mishra SS, Das R, Dhiman M, Choudhary P, Debbarma J, et al. (2017) Present Status of Fish Disease Management in Freshwater Aquaculture in India: State-of-the-Art-Review. J Aquac Fisheries 1: 003.

Received: August 03, 2017; Accepted: September 11, 2017; Published: September 25, 2017 sector in India, enhancing productivity, socioeconomic condition and livelihood security of fishers who are directly or indirectly dependant on this sector. The details of freshwater aquaculture practices, prevalence of disease, principle of disease diagnosis and control programme and future scope of development of freshwater aquaculture in India, have been elaborated.

Keywords: Antibiotics; Anti-parasitic; Aquaculture; Chemicals; Feed supplements; Fish health management; Probiotics

\section{Introduction}

There is global need for food and nutritional security especially amongst developing and under-developed counties [1]. Fisheries in India, is a progressively growing sector with varied resources. It has been estimated that more than 14.50 million people at the primary level are directly or indirectly dependant on this sector for their livelihood security. The sector has shown significant growth from traditional culture practices to commercial methods of culture, enhancing fish production from a mere 7.5 lakh tonne in 1950-51 to 107.95 lakh tonne during 2015-2016, while earnings has of Rupees 33,441 crore in 2014-15 (US $\$ 5.51$ billion) through export of fish to different countries [2-4]. Fisheries and aquaculture sector has achieved a significant overall annual growth rate of about $4 \%$ during the $11^{\text {th }}$ Five Year Plan period. As such fisheries and aquaculture has made contribution of about $0.91 \%$ to the National Gross Domestic Production (GDP) and 5.23\% to the agricultural GDP (2014-2015), which is very significant $[2,5]$. At present India contributes about $6.30 \%$ to the global fish basket and 5\% of global fish trade [6]. India is the second largest fish producing country and hold second largest aquaculture producing nation in the world [2]. While, Asia contributes more than $90 \%$ to the world's aquaculture production, India now takes the second position with regard to annual fisheries and aquaculture production, only after China [5]. As per FAO data, aquaculture has been the fastest growing food producing sector in the world, with an average annual growth rate of $8.9 \%$ since 1970 , compared to only $1.2 \%$ for capture fisheries and $2.8 \%$ for terrestrial farmed meat production systems over the same period [7]. During the year 20152016, the country has produced about Indian Rupees 1.0 lakh crore value fish for local consumption and export [8]. This resulted in an unparalleled average annual growth rate of over 4.5 percent over the years which has placed the country on the forefront of global fish production $[3,8]$. The country has plans to increase the fish production and productivity by 8 per cent annual growth rate and to reach 15 million tonnes mark by 2020 [9]. This sector is also a principal source of livelihood for a large section of economically underprivileged population of the country and more than 14.5 million people depend on fisheries activities [10]. However, progress of aquaculture has caused some unwarranted activities both for the species and environment. At the same time, over-exploitation of fisheries and anthropogenic stress on aquatic ecosystems has placed pressure on wild fish populations. The consequence has been the emergence and spread of an increasing array of new diseases change. As has been noticed in other food producing sector, aquaculture has been adversely affected due to frequent occurrence of disease outbreaks mostly due to intensive culture practices for higher economic gain [11]. This review examines the development and characteristics of freshwater 
aquaculture practices in India, major fish diseases, principle of disease diagnosis and control programme and future scope of development of freshwater aquaculture in India. It also considers the potential challenges for heath management issues in aquaculture for sustainable development.

\section{Aquaculture Production Status in India}

By virtue of its geographical situation in the monsoon belt, India is endowed with good rainfall. As a consequence, it has extensive potential aquaculture area in the form of ponds and tanks. These water bodies are distributed throughout almost all the states of India. In India the aquatic resources are vast and diversified. As per the record of Department of Animal Husbandry, Dairying and Fisheries, Government of India records, the country has varied potential aquatic which includes $1.95 \mathrm{~km}$ of rivers and canals, 7.95 lakh hectare (ha) of floodplain wetlands, 24.33 lakh ha of freshwater ponds and tanks, 29.26 lakh ha of reservoirs and 11.55 lakh ha of brackish water ponds [2]. Besides, the country has 19134 small reservoirs, 180 medium and 56 large reservoirs, with a total water surface area of 1485557 ha, 527541 and 1140268 ha, respectively [12-13]. Cage culture is practised in open water resources especially in reservoirs and lakes. The major aquatic resources, aquaculture practices being followed in India and their management modes are given in table 1. Freshwater aquaculture contributes to over 95 percent of the total aquaculture production [3-4]. It accounts for nearly $55 \%$ of the total fish production in India (Figure 1). The sector has benchmarked from a domestic activity in Eastern Indian states of West Bengal and Odisha to an enterprise in the states like Andhra Pradesh, Punjab, Haryana, Maharashtra, etc. taking up fish culture as a trade and enterprise. The largest area under aquaculture being in the state of Andhra Pradesh (0.52 mha), followed by Karnataka $(0.41 \mathrm{mha})$ and West Bengal $(0.276 \mathrm{mha})$. These three states account for about $50.5 \%$ of India's aquaculture areas [14]. The fish production status during 2012-2013 in different states table 2 indicates that out of total 90,19,148 tonnes total fish production, inland fisheries contributed to 57,44,057 tonnes with maximum contribution by Andhra Pradesh (13,93728 tonnes), followed by West Bengal (13,37,664 tonnes) [8]. Besides these other states like Karnataka, Maharashtra, Odisha, Chhattisgarh, Jharkhand and Gujarat also contributed significantly to freshwater fish basket in India (Table 2). The freshwater aquaculture comprises of the culture of mainly three species of Indian Major Carps (IMC) viz. Catla catla (Catla), Labeo rohita (Rohu), and Cirrhinus mrigala (Mrigal) with three exotic species Hypophthalmichthys molitrix (Silver carp), Ctenopharyngodon idella (Grass carp), and Cyprinus carpio (Common carp) through polyculture of either only Indian Major Carps (IMC) or combination of Indian and exotic carps Kathia et al., [14]. Culture of catfishes (air breathing and non-air breathing), Giant freshwater prawn Macrobrachium rosenbergii (Scampi), pangasius (Pangasiandon hypophthalamus) and culture of tilapia (Oreochromis niloticus; Oreochromis mossambicus) are also practised in freshwater aquaculture. Production of IMCs contribute between $70 \%$ and $75 \%$ of the total freshwater fish production, while silver carp, grass carp, common carp and catfish make up $25 \%$ to $30 \%$ of the production.

However, currently, only an estimated $40 \%$ of the available resources in India, is in use for aquaculture because of technical and market access issues and there is lot of scope of development of aquaculture [5]. With technological inputs, productivity has gone up from $500-600 \mathrm{~kg} / \mathrm{ha}$ to $3000 \mathrm{~kg} / \mathrm{ha}$, with several farmers and entrepreneurs achieving higher production levels of $6-8 \mathrm{t} / \mathrm{ha} / \mathrm{yr}$. The national average productivity has increased from $50 \mathrm{~kg} /$ hectare/year in 1974-1975 to about 2,135 kg/hectare/year in 1994-1995 and 2,270 kg/hectar/ year in 2003-2004 [15-16]. However, as indicated by Siddick et al., [17], the most common constraints of aquaculture production in India include, i) Lack of perennial rivers, tanks and ponds with year the round availability of water ii) Frequent erratic and inadequate rain fall iii) Mismatch of monsoon rain and breeding season (May-August) of IMC iv) Lack of awareness among the farmers on improved methods of fish cultivation and better Management Practices (BMPs) in aquaculture, v) Improper coordination with production, demand and supply of fish and fish-seed vi) Non availability of quality fish-seed for stocking vii)Under-utilization and poor management of water bodies by local authority or cooperatives and viii) Lack of suitable public policies on long-term lease of water bodies or giving ownership, in some states [17].

\begin{tabular}{|c|c|c|c|}
\hline S. no & Resource & Size & Management Mode \\
\hline 1. & Rivers & $54,000 \mathrm{~km}$ & Capture fisheries \\
\hline 2. & $\begin{array}{c}\text { Medium and large } \\
\text { reservoirs }\end{array}$ & 16.86 lakh ha & Capture fisheries \\
\hline 3. & Small reservoirs & 14.86 lakh ha & Culture based fisheries \\
\hline 4. & Flood plain wetlands & 5.42 lakh ha & Culture based fisheries \\
\hline 5. & Freshwater ponds/tanks & 23.8 lakh ha & Aquaculture \\
\hline
\end{tabular}

Table 1: The major freshwater aquatic resources, aquaculture practices being followed in India and their management modes [13].

Total aquaculture production for the Republic of India (tonnes)
Source: FAO FishStat

7500000

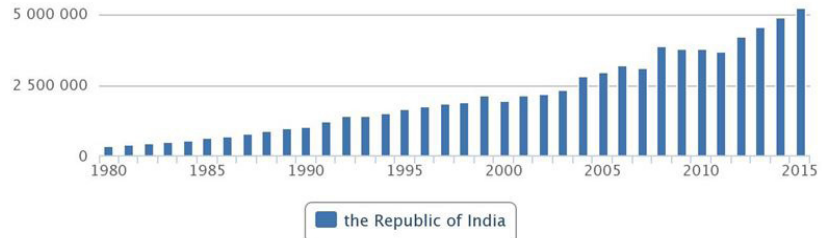

Figure 1: Showing growth total aquaculture production status in India [4].

\section{Disease Problems in Indian Aquaculture}

Disease is one of the major constrains to aquaculture and limiting factor for economic and socio-economic development in India and as in many other countries of the world [18-20]. Some diseases have caused serious damage, not only the livelihood of fish farmers, but also, to the future development of the industry. Many diseases affecting present day aquaculture is resultant of intensification of culture practices without the basic perception of intricate balance between host, pathogen and environment [7,21]. In India, the increase in aquaculture production particularly in expansion into intensive and semi-intensive methods of production has been coupled by increase in fish and shellfish resulting from high stocking densities and stress conditions that favours the occurrence and spread of infectious diseases [22]. A total loss of one billion US \$ was reported due to diseases in shrimp culture [23]. The vertical expansion of fish culture with diversified species and higher stocking density has resulted more frequent occurrence of bacterial, parasitic and viral pathogens, often leading to higher morbidity or mass mortalities and lowered production. Rural resource poor farmers with little or no knowledge of fish health management and skill to prevent and control disease 
outbreaks are the most sufferers, incurring huge economic loss [18]. It is understood that occurrence of disease is a result of the complex interaction between the host, the pathogen and the environment [24]. In aquatic systems, disease management is a difficult proposition due to the unique ecosystem, where the pathogen is always looking for an opportunity when the health status of the host is compromised [25]. In many cases, disease outbreaks are closely related to environmental deterioration, leading to stress to the cultured animals. Different stress factors such as non-optimal water quality, higher microbial load, poor nutritional status, high stocking density can trigger the chances of infection by opportunistic pathogens in aquatic environment [26]. Most bacterial, parasitic and fungal pathogens are not strictly parasitic micro-organisms. These pathogens have a high adaptability to environmental changes. If the conditions for parasitism are unsuitable, saprophytic relationship will develop. Environmental stress factors can result in increased occurrence of fungal infections. High organic loadings were also identified as a cause of increased infection of Saprolegnia parasitica [27].

\begin{tabular}{|c|c|c|c|c|}
\hline S. No. & State & Marine & Inland & Total \\
\hline 1 & Andhra Pradesh & 414349 & 1393728 & 1808077 \\
\hline 2 & Bihar & 0 & 400140 & 400140 \\
\hline 3 & Gujarat & 6933500 & 92586 & 786086 \\
\hline 4 & Karnataka & 373167 & 202216 & 575383 \\
\hline 5 & Kerala & 484392 & 149098 & 633490 \\
\hline 6 & Madhya Pradesh & 0 & 85165 & 85165 \\
\hline 7 & Maharashtra & 433684 & 145110 & 578794 \\
\hline 8 & Odisha & 118311 & 291832 & 410143 \\
\hline 9 & Tamilnadu & 428441 & 191956 & 620397 \\
\hline 10 & Uttar Pradesh & 0 & 449750 & 449750 \\
\hline 11 & West Bengal & 152352 & 1337664 & 1490016 \\
\hline 12 & Chhattisgarh & 0 & 255611 & 255611 \\
\hline 13 & Jharkhand & 0 & 96600 & 96600 \\
\hline 14 & All States together in India, & 3275091 & 5744057 & 9019148 \\
\hline
\end{tabular}

Table 2: State-wise production of fish in India during 2012-13 (In tonnes) [8].

\section{Common Diseases Reported in Freshwater Aqua- culture}

India is basically a carp country and indigenous Indian Major Caps (IMC) which include rohu (Labeo rohita), Catla (Catla catla), mrigal (Cirrhinus mrigal), exotic carps like common carp (Cyprinus carpio), grass carp (Ctenopharyngodon idella) silver carp (Hypophthalmicthys molitrix) along with catfishes (Clarius batrachus, Heteropneuestes fossilis, Pangassius spp.) and freshwater prawn Macrobrachium rosenbergii also being widely cultured account for bulk of aquaculture production. In last few years, the exotic catfish Pangasiandon hypophthalamus, and pacu, Piaractus brachypomus, culture are also increasing. Also Tilapia and Pangasius offer opportunities, for cage culture freshwater lakes and reservoirs. Instead of 10 ton per ha, in pond culture system, now a fish production of 3.0 ton in a cage of $6 \mathrm{ft} \times 4 \mathrm{ft} \times 4 \mathrm{ft}$ can be achieved. The focus has been on the production of genetically improved tilapia for market of cheap source of proteins [5]. However, carp production contributes to bulk of the fish production in Indian freshwater aquaculture, with production over 3.25 million tonnes. As there is limited scope for horizontal expansion, the current trend in aquaculture development is towards intensification of culture practices. However, frequent occurrence of diseases and epizootics are considered to be major bottlenecks for increasing production. It is estimated that disease account for $10-5 \%$ towards the production cost [28]. The diseases are mostly of bacterial and parasitic origin and involvement of fungal pathogens and viruses are rarely reported in Indian aquaculture practices.

\section{Bacterial diseases}

Bacterial fish diseases are very common and are one of the most difficult health problems to deal with. These bacteria are generally saprophytic in nature and only become pathogenic when fishes are physiologically unbalanced, nutritionally deficient, or there are other stressors, i.e., poor water quality, overstocking, which allow opportunistic bacterial infections to proceed [29]. Bacterial diseases have been frequently encountered in eggs, fry, fingerlings of fish, causing heavy mortality. These microorganisms are essentially opportunistic pathogens which invade the tissues of a fish host rendered susceptible to infection by stress factors [12]. Occurrence of bacterial diseases was not considered to be a serious problem in our country, as economic losses in fish culture was not known. The incidences of Ulcerative disease (EUS) in various Southeast Asian countries as well as in India, focused tremendous attention on the threat the disease epidemics hold for the farmers. Economic losses of the order of US \$ 10 million in Thailand and over $3 \$$ million in Bangladesh were lessons enough to realize their importance [30]. Some of the important bacterial diseases like motile aeromonads septicaemia caused by Aeromonas hydrophila, edwardsiellosis caused by Edwardsiella tarda, Pseudomonas septicaemia by Pseudomonas fluorescens and Pseudomonas putrefaciens, flexibacteriosis by Flexibacter columnar, Vibriosis by Vibrio alginolyticus and V. parahaemolyticus bacterial gill disease, streptococcal septicaemia, mycobacteriosis, disease, and enteric septicaemia, are often being reported in carp culture in India [30-31]. In general there are four types of bacterial infections i) Fin rot - usually resulting from environmental stress, ii) Bacterial body ulcers-open, shallow to deep, lesions on the fish's body iii) Bacterial gill disease in which the gills are the primary target iv) Systemic bacterial disease, in which bacteria invade and cause damage to internal organs $[29,32]$. The details of common bacterial diseases reported in aquaculture have been presented in table 3 .

Another bacterial disease commonly reported in fish culture is bacterial skin disease or red disease. It is a systematic bacterial infection. There are red areas on body, depression with swollen eyes and abdomen. A wide variety of bacteria mainly belonging to Gram-negative rods are involved. Many pathogens are present only at skin lesions, especially Flexibacteria, Aeromonads, Vibrios etc. There may be necrotic lesions on fins (fin rot). The disease may become systematic, more severe form causing mortality. Another important bacterial disease often confused with red disease in carp culture in Motile Aeromonas Septicaemia (MAS). This is probably the most common bacterial disease causing severe production loss to freshwater fish culture. This disease has been associated with several members of the genus Aeromonas, including A. hydrophila, A. sobria, A. caviae, A. schuberti, and A.veronii [31]. The clinical signs of motile Aeromonas septicaemia include high morbidity often with superficial to deep skin lesions and sometimes sudden death with or without any clinical symptoms. Skin lesions are often noticed at base of the fins, with variously sized areas of haemorrhage and necrosis. There are red areas on body, skin ulcers, swollen body, abdomen and eyes and musculature, hence often called as "red-disease". These lesions may progress to reddish to grey ulcerations with necrosis of the underlying. Unless immediate action not taken, the mortality rate often reached to $100 \%$. 
Citation: Mishra SS, Das R, Dhiman M, Choudhary P, Debbarma J, et al. (2017) Present Status of Fish Disease Management in Freshwater Aquaculture in India: State-of-the-Art-Review. J Aquac Fisheries 1: 003.

\begin{tabular}{|c|c|c|c|}
\hline SI No & Disease Condition & Symptoms & Involvement of Pathogens \\
\hline \multicolumn{4}{|c|}{ A. Bacterial diseases } \\
\hline 1 & Columnaris Disease & $\begin{array}{l}\text { Haemorrhagic and ulcerative lesions on fins, head, back, which may look } \\
\text { yellow to orange due to bacterial growth and pigmentation. }\end{array}$ & $\begin{array}{l}\text { Flavobacterium columnare (Flexibacter/ } \\
\text { Cytophaga columnaris) }\end{array}$ \\
\hline 2 & Tail rot and Fin rot & Erosions, discoloration and disintegration of fins and tails. & $\begin{array}{l}\text { A.hydrophila, Pseudomonas spp. Cy- } \\
\text { tophaga spp., Haemophilus }\end{array}$ \\
\hline 3 & $\begin{array}{l}\text { Bacterial gill disease or Gill rot or } \\
\text { Environmental disease }\end{array}$ & $\begin{array}{l}\text { Gasping, lethargic, gills look discoloured with trapped materials, secondary } \\
\text { fungal infection }\end{array}$ & $\begin{array}{l}\text { Flavobacterium branchiophilum, Cy- } \\
\text { tophaga spp., Flexibacter spp }\end{array}$ \\
\hline 4 & $\begin{array}{l}\text { Aeromoniasis or Motile aeromonas } \\
\text { septicaemia }\end{array}$ & Haemorrhagic and ulcerative lesions on skin fins, head, exopthalmia & $\begin{array}{l}\text { Aeromonas hydrophila, A veronii bv. } \\
\text { Sobria, A. sobria }\end{array}$ \\
\hline 5 & $\begin{array}{l}\text { Edwardsiellosis or Edwardsiella } \\
\text { septicaemia }\end{array}$ & $\begin{array}{l}\text { Ulcerative abscesses in internal organs, haemorrahic ulcers on skin, fins } \\
\text { and body, rectal protrusion }\end{array}$ & Edwardsiella tarda \\
\hline 6 & Vibriosis & $\begin{array}{l}\text { Ulcerative abscesses in internal organs, haemorrahic ulcers on skin, fins } \\
\text { and body }\end{array}$ & $\begin{array}{l}\text { Vibrio anguillarum, V. parahaemolyticus, } \\
\text { V.alginolyitucs }\end{array}$ \\
\hline 7 & Eye disease & Cataract of eyes, affect cornea, eyeball gets putrefied & $\begin{array}{l}\text { Aeromonas liquefaciens, Staphylococcus } \\
\text { aureus, various other bacteria }\end{array}$ \\
\hline 8 & $\begin{array}{l}\text { Pseudomoniasis/Psedomonas } \\
\text { septicaemia }\end{array}$ & Haemorgaic lesions on skin, fins, tail & $\begin{array}{l}\text { Pseudomonas sp. Pseudomonas } \\
\text { fluorescens }\end{array}$ \\
\hline 9 & Enteric Red Mouth Disease (ERM) & Haemorgaic lesions on skin around mouth, fins, tail. Internal haemorrhages & Yersinia ruckeri \\
\hline \multicolumn{4}{|c|}{ B. Fungal diseases } \\
\hline 1 & Saprolegniasis & $\begin{array}{l}\text { Fungi usually grow on dead organic matter of pond bottom. Fish become } \\
\text { weak, ulceration of skin with haemorrhages, cotton wool growth on ulcers } \\
\text { with grey patches }\end{array}$ & Saprolegnia parasitica, \\
\hline 2 & Branchiomycosis (Gill rot disease) & $\begin{array}{l}\text { Fungi usually grow on heavily deposited decaying organic matter of pond } \\
\text { bottom. Fish become lethargic, redness of gills, which later become gray- } \\
\text { ish-white, necrosis of gill filaments }\end{array}$ & Branchiomyces demigrans \\
\hline 3 & Epzootic Ulcerative Syndrome (EUS) & Fish become lethargic, redness of skin, ulcerative patches, high mortality & $\begin{array}{l}\text { Aphanomyces invadans sp. (Fungs), } \\
\text { Aeromonas hydrophila, A. sobria }\end{array}$ \\
\hline \multicolumn{4}{|c|}{ C. Parasitic diseases } \\
\hline & $\begin{array}{l}\text { Ichthyophthiriasis (Ich/White spot } \\
\text { disease) }\end{array}$ & $\begin{array}{l}\text { Most fish are susceptible. Whitish cysts of around } 1 \mathrm{~mm} \text { diameter, mostly } \\
\text { observed on skin, fins and gills. }\end{array}$ & Ichthyophthirius multifiliis \\
\hline 2 & Trichodiniasis & $\begin{array}{l}\text { Most fish are susceptible. Whitish cysts observed on skin, fins and gills. } \\
\text { Disc shaped, spherical cysts can be observed in whitish material under } \\
\text { microscope. }\end{array}$ & Trichodina sp. \\
\hline 3 & Dactylogyrusis (Gill fluke) & $\begin{array}{l}\text { Mostly affects gills, destroying the gill filaments, gills with clumps of white } \\
\text { masses. Parasites can be observed under microscope in sample from gills }\end{array}$ & Dactylogyrus \\
\hline 4 & Gyrodactylosis(Skin fluke) & $\begin{array}{l}\text { These parasites which grow on and destroy the skin, gills with clumps of } \\
\text { white masses, frequently associated with secondary infections. }\end{array}$ & Gyrodactylus spp. \\
\hline 6 & Argulosis (Carp lice) & $\begin{array}{l}\text { Wide spread in most cultured \& ornamental fish species in India. Parasite } \\
\text { is seen moving on the skin surface, causing skin lesions with secondary } \\
\text { bacterial infections, haemorrhagic spots and ulcers. }\end{array}$ & Argulus spp. \\
\hline 7 & Myxosporidiasis & $\begin{array}{l}\text { Parasite produces cysts on different parts of body, internal organs and gill } \\
\text { filaments. Fish becomes weak, falling of scales. On microscopic observa- } \\
\text { tion, typical cysts can be observed in gill squash. }\end{array}$ & Myхosporidium spp. \\
\hline
\end{tabular}

Table 3: Common diseases recorded from cultivable species of fish in India.

Other bacterial diseases of less importance are Edwardsiellosis, caused by Edwardsiella tarda and Enteric Red mouth Disease, caused by the pathogen Yersinia ruckeri. There are some reports of occurrence of Columnaris bacterial disease that affects the skin or gills of freshwater fish and is caused most commonly by Flexibacter columnaris. This is primarily an epithelial disease and necrosis and erosions of the skin and gills are often observed which may become systemic. Whitish plaques with reddish peripheral zone are observed mostly on the head or back, hence the disease also called saddleback disease. Lesions on fins arte also often observed, hence it is also called as fin rot disease.

\section{Parasitic diseases of fish}

The production from culture system is hampered by the infestation of various fish parasites. Compared to other diseases, occurrence of parasitic disease has been the major cause of concern and caused significant setback to freshwater aquaculture in India [20]. Fish parasites multiply rapidly under favourable conditions, there by affecting the health of fishes, often leading to high mortality. Parasites interfere with nutrition of hosts, disrupts metabolism and secretary functions of alimentary canal and damage nervous system [29,33]. During survey of different carp and Pangasius farms in Andhra Pradesh, Odisha, Karnataka and Gujarat, fish were observed to be affected by fish parasites, mostly, the protozoan ciliates (Ichthyophthirius sp., Trichodina $s p$.), monogenetic trematodes (Dactylogyrus spp., Gyrodactylus $s p$.) and larger crustacean ectoparasites viz. Lernae spp., Argulus spp., (the freshwater louse,) Ergasilus, which cause substantial economic loss in fish culture system in India [20,22,26]. Disease and mortality 
due to monogenian trematodes Gyrodactylus spp., (commonly known as skin flukes), and Dactylogyrus spp., (known as gill flukes) have also been commonly reported in carp culture and cage culture. These monogenetic trematodes are considered as one of the most prevalent parasitic agents affecting skin and gills, causing irritation and destruction of gill tissues leading to impairment of breathing. The Ichthyopthirius, cause "white spot" or "Ich" in most freshwater fishes. Another fish parasite, Trichodina browse over gills and skin, damaging the host tissue and consuming the resulting dead tissues. Repeated chemical treatments are necessary to eliminate the parasites [26]. Another important and most prevalent parasitic disease causing severe economic loss in carp culture is "Argulosis" caused by crustacean ectoparasites of the genus Argulus also called "freshwater fish lice" [20]. Acute infestation of Argulus infestations often cause dermal ulceration, osmotic imbalance, physiological stress and immunosuppression, leading to high morbidity and lowered growth rate of carps $[30,33]$, but the incidence of mass mortality due to this disease has been very low [34]. Reported that Indian major carps are more susceptible to Argulus parasites, in comparison to Chinese and European carps. The intensity of infestation is greatly influenced by seasonality, which affects host physiology and ecology [30,34]. Intense parasite infestation can cause ulceration and upset the normal course of reproduction [33]. Besides, indirect effects of infestation such as reduced fish growth, reduced feed conversion ratio, secondary infections with other bacterial and parasitic infestations and fish mortality as well as farmers perception about safe aquaculture, too contribute substantially to the loss incurred [30].

Among all fish parasitic infestations, disease with Argulous is most common (29\%), followed by infestation with Dactylogyrous $(25 \%)$ and Myxobolous (9\%) (Figure 2). However, in some cases infestation with multiple parasites have also been reported in fish culture. It has been observed that incidence of Argulosis in the wild fish populations is of very low in intensity compared to that reported in pond culture conditions [35]. Loss due to parasitic disease Argulosis was been estimated to be to the tune of Rupees 30,000 (US\$ 615) per hectare per year in carp culture in India [28]. However, [34] estimated loss of BDT 35,552.50 ha-1 yr-1 due to parasitic diseases in carp cultures in Bangladesh. Overall loss due to parasitic diseases was found $11 \%$ for mortality, $11 \%$ for chemicals cost and $65 \%$ for reduction of growth of carps in the study areas.

\section{Fungal diseases of fish}

Contrary to bacterial and parasitic diseases, only a few number of fungal species are known to be pathogenic to fish. Mostly these are present in water and under unfavourable conditions, they attack the fish causing skin lesions. Most fungal infections recorded in carp culture are those caused by species belonging to the oomycete fungi, Saprolegnia, Achlya and Aphanomyces. Diseases caused by these fungi are collectively called "saprolegniasis" [22]. These oomycete fungi, are commonly present in aquatic environments, are rarely considered to be primary pathogens. These are often recognized as saprophytic, opportunistic secondary pathogens that readily colonise the damaged tissues infected by bacteria or parasites [30]. Fungal growths on skin or fins look like patches of white to whitish-grey cotton-wool like growths. These are mostly composed of numerous fungal hyphae, which can be visualized under microscopic observation Saprolegniasis is particularly prevalent in over-wintering ponds with a high stocking density, like in cage culture or intensive aquaculture. Although there are several reports of saprolegniasis mostly is cage culture systems, the incidences are normally less in pond culture system, unless there is gross mismanagement. Besides Saprolegnia, Branciomyces and Aphanomyces causes disease in pond aquaculture.

Another important fungal induced disease in fish culture of high economic importance is Epizootic Ulcerative Syndrome (EUS). It is widely occurred in freshwater aquaculture causing a great loss in South East Asia including India. It is a severe and economically important disease affecting farmed freshwater fish and listed as a notifiable disease. Haemorrhages and ulcers are the clinical manifestation of the disease symptoms on the body surfaces. It is an important bacterial-fungal mixed infection responsible for high mortality in freshwater fishes. Fish species commonly affected are Catla catla, L. rohita, C.mrigala, C. carpio, Channa sp., Puntus sp., and G. chapra [22]. Affected fishes become weak, off-fed and float on the surface of the water. Initially, red coloured lesions often with haemorrhages are seen on skin, which gradually becoming deeper and assuming the form of ulcers. In some cases tissues patches fall off, causing secondary infection and high mortality [36]. Although a wide variety of organisms have been isolated from the body surfaces and internal organs of the fish, Aphanomyces invadrans is believed to be the primary causative organism [18]. A range of both biotic and abiotic factors may predispose fish to infection by EUS [18], reported EUS to be the most common disease in Bangladesh that has a significant impact on carp culture they indicated that ponds receiving water from rice field and river/ditch had high relative risk of EUS [18]. The details of fungal disease in fish culture has been presented in table 3.

Farmers in the region are in practice of using various probiotic formulations, aqua drugs and chemicals, various antimicrobials, sanitizers, anti-parasitic drugs and even antibiotics in fish culture system, as preventive and control measures to protect the crops. Some drugs and preparations, which are used in animal medicine and agriculture practices are also being used in fish culture [37]. CIFAX, a chemical formulation developed by the scientists of ICAR-CIFA, has been found quite useful in controlling EUS and other bacterial infections, besides have some other useful actions in pond culture [38].

\section{Viral diseases for fish}

There are more than 125 different viruses have been identified in fish around the globe and new viruses are being discovered every new date. However, there are only few reports of viral diseases affecting finfish in India. Viral diseases like Cyprinid Herpesvius-2 (CyHV-2), Koi Rana Virus (KIRV), Carp Edema Virus (CEV), Megalocytiviris and Goldfish haematopoietic virus necrosis herpes have been reported in ornamental fish culture [28]. KIRV causing huge mortality of koi Cyprinus carpio was reported in ornamental fishery. In addition, koi sleepy disease caused by CEV was reported in Cyprinus carpio [39]. Report of Viral Encephalopathy and Retinopathy (VER) or Betanoda virus was also reported for a period in seabass farming, although there were no subsequent reports of such disease occurrence in India. There are some reports of occurrence of Tilapia Lake Virus (TILV) in some pockets of tilapia culture in cages and tanks. However, Indian Native Species of Carps (IMC), which is the predominant species is not affected by any of above describes viruses, which is a good sign for Indian aquaculture sector. Overall the freshwater aquaculture sector is free from adverse impact of fish viral epidemics as has been reported in marine or brackish water shrimp culture and in other parts of the world.

The pattern of disease occurrence and mortality is typical in Indian aquaculture system. While occurrence of viral disease especially 
White spot disease, has caused havoc in shrimp aquaculture, viral disease outbreaks has not been the cause of concern in fish culture. The significant observation is that so far not a single case of viral disease outbreak has been reported in freshwater aquaculture in India, causing huge mortality. May be that India is blessed with Indigenous Variety of Indian Major Carps (IMCS) which are not susceptible to fish viral pathogens as prevalent in other Asian countries or the culture environment is not conducive for the viral pathogens to multiply and cause disease. However, frequent occurrence of parasitic infestations in fish culture has been an area of concern, which is responsible for high morbidity and production loss, compared to other pathogens. As has been presented in figure 3 , incidences of occurrence of parasitic infestations in freshwater aquaculture are maximum (46\%), followed by loss due to alternation in water quality parameters (24\%) leading to production loss. Infection of fish with bacterial pathogens are in the range of $22 \%$ and in only $8 \%$ cases the mortality are due to other factors (Figure 3).

Another significant observation in Indian aquaculture has been seasonal variation in occurrence and severity of fish diseases in freshwater aquaculture (Table 4). Whereas incidences of red disease or Aeromoniasis are common during all seasons, the incidences of Black-gill disease are more during winter periods. Among parasitic diseases, occurrence of Argulousis and gill fluke disease are comparatively more during winter and post-rainy season. Hence, the farmers are advised to take due preventive and control measures during postrain and winter seasons in grow-out culture system.

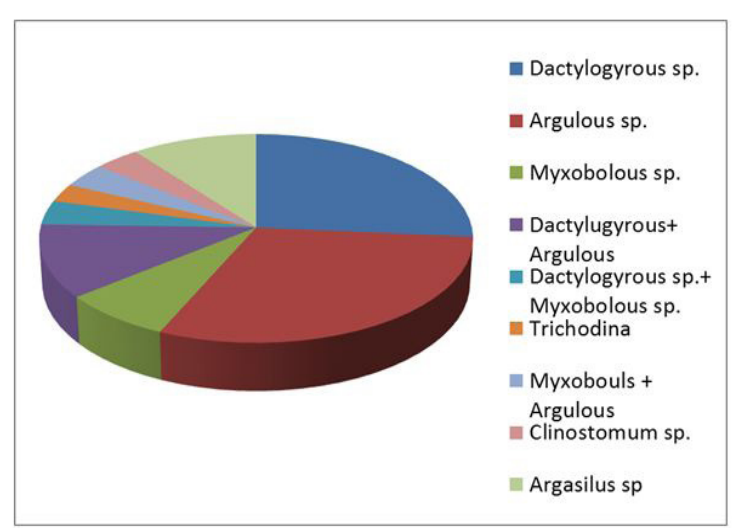

Figure 2: Occurrence of single and/ multiple parasitic infestations in freshwater aquaculture.

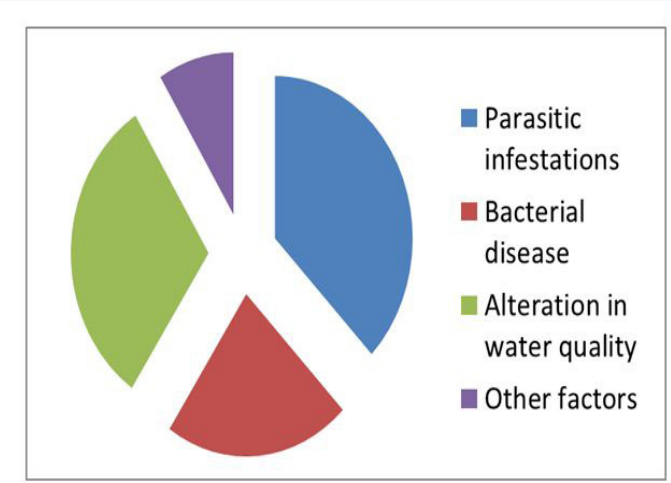

Figure 3: Different causative factors responsible for mortality and production loss in freshwater aquaculture.

\section{Principles of Disease Diagnosis and Control Pro- gramme}

The impacts of emerging diseases of aquatic animals have been substantial, adversely affecting livelihood security of millions and have impacted regional or national economies [11]. The most devastating production loss with socioeconomic impacts was that observed in in shrimp aquaculture in India during 1995-1998, which almost led to collapse of shrimp aquaculture industry in India [40]. Development and application of suitable diagnostic and control measures to combat disease occurrence in fish and shellfish culture to control production loss, thus have assumed significance in many aquaculture-producing countries [21]. The most important approach to disease control programme is managing the culture unit to reduce disease predisposing conditions. This is best achieved through the use of realistic stocking densities, preventing the introduction of pathogens into culture systems or hatcheries, maintenance of good water quality parameters, avoiding stress and through the provision of adequate nutrition to cultured animals. Until few years from now, diseases in aquatic organisms were not considered to be a serious problem in our country, as economic losses in fish culture were not known. Recent incidences of various emerging diseases have focused attention in this aspects. However consolidate affords are necessary to tackle this problems for sustainable aqua farming and to prevent production losses [22,29]. As elaborated by Subasinghe et al., [21] and Bondad-Reantaso et al., [7], the essential principles of disease treatment and control are to i) establish an accurate diagnosis; ii) select an appropriate and environmentally responsible treatment and iii) evaluate management practices within the farm and determine if future outbreaks could be prevented by changes in procedure or design. At National level, the laboratory facilities, diagnostic expertise, control protocols and therapeutic strategies are becoming better day by day to handle such disease outbreaks. In addition, many farmers, especially in developed countries, have improved their capacity to respond quickly and effectively to emergent disease situations [21]. It has been emphasized to establish such composite "Water quality testing- disease diagnosis Laboratory" required to be set up at every district level, specifically in aquaculture zones to tackle the problem. Considering the present condition, it is presumed unless there intra-state and inter-state cooperation and coordination, it would be difficult to implement it. If implemented, this would greatly Enhanced their disease prevention awareness.

\section{Future Scope of Development of Aquaculture in India}

Data indicate currently, only an estimated $40 \%$ of the available resources in India are in use for aquaculture because of technical and market access issues and there is lot of scope of development of aquaculture [5]. Realizing the immense scope for development of fisheries and aquaculture, the Government of India has restructured the Central Plan Scheme under an umbrella of "Blue Revolution". The restructured Central Sector Scheme on Blue Revolution called Integrated Development and Management of Fisheries (CSS) approved by the Government provides for a focused development and management of the fisheries sector to increase both fish production and fish productivity from aquaculture and fisheries resources of the inland and marine fisheries sector including deep sea fishing [9]. Blue Revolution, the Neel Kranti Mission has the vision to achieve economic prosperity of the country and the fishers and fish farmers as well as contribute towards food and nutritional security through full potential utilization of water resources for fisheries development in a sustainable manner, 
keeping in view the bio-security and environmental concerns [2]. Under Blue revolution scheme, specific target has been made to enhance the fish production from present level of 107.95 lakh tonnes to about 150 lakh tonnes by 2020. It would lead to augmentation of export earnings, which would directly and indirectly benefit the fishers and fish farmers, with nearly doubling their income. The Department of Animal Husbandry Dairying and Fisheries (DAHDF), Ministry of Agriculture, Government of India, has prepared a detailed proposal called "National Fisheries Action Plan-2020" (NFAP) for the next 5 years with sole objective of enhancing fish production by 8 percent annual growth rate, to achieve the concept of Blue Revolution. The mission would be operated through National Fisheries Development Board (NFDB) in collaboration with State Governments and ICAR Research Institutes, for their specific components [9].

However, there remain some impediments which need to be tackled to have enhanced fish production in India. As suggested by Siddick et al., [17], the productivity of water bodies can be further improved by i) Stocking right mix of fast growing fish varieties in recommended quantities ii) Indian Major Carps (IMC) being the most demanded fish species in the region, seed production hatcheries to be made available near to the culture sites, iii) Research work need to be taken up in developing fast growing fish varieties suitable for short seasonal tanks iv) Stocking with right composition of fish seeds need to be taken up to utilize natural feed available in different levels of water column. Again, there is considerable potential for promoting scientific fish culture practices in community ponds or open-water resources [17]. Besides modern culture practices, research on disease surveillance, pathogen zoning and disease forecasting would help to take up suitable preventive and control measures to protect the crops against eventualities. Considering the importance of fish disease surveillance in health management Network of Aquaculture Centres in Asia-Pacific (NACA), Bangkok, in their meeting during April 2012, made a strong recommendation for the need for a national program on surveillance. This was followed up by the development of a project proposal by the ICAR-National Bureau of Fish Genetic Resources (NBGFR),Lucknow, India, in consultation with national partners and NACA [41]. In this regard, DAHDF, Government of India, has already approved a "National Surveillance Programme on Aquatic Animal Disease", through the National Fisheries Development Board, Hyderabad, in collaboration with State Agricultural Universities (SAUs) and ICAR Research Institutes. Besides this, Indian Council of Agricultural Research (ICAR) has already implemented a national programme "All Indian Network Project on Fish Health" through ICAR - Research Institutes and SAUs [42]. The project aims to understand the disease prevalence status, economic loss caused due to disease, cataloguing of various drugs and chemicals used in aquaculture and conducting fish health camp and awareness programme for the benefit of farmers. Efforts are also being made to bring a "National inland fisheries Policy" along with new "National Marine Fisheries Policy", which will decide an overall and integrated growth frame work in the area of inland fisheries throughout the country [2], which would lead to sustainable development of aquaculture in India.

\section{Conclusion}

Fisheries in India is an expanding industry, with varied aquatic resources and potential, engaging over 14.50 million people at the primary level and many more along the value chain. Transformation of the fisheries sector from traditional to commercial scale has led to an increase in fish production from 7.5 lakh tonne in 1950-1951 to 107.95 lakh tonne during 2015-2016, while the export earnings from the sector registered at around 33,441 crore (US $\$ 5.51$ billion) in 2014-2015 [9]. In fish production, India is constantly at the second position after China. While, India has made a sufficiently fast progress in achieving production of 7.2 million ton, and aiming for doubling it by 2020, there remains an opportunity for further increasing the production of fish from inland water bodies like reservoirs, wetlands, lakes and canals. Cage culture has the potential application in such water bodies and the results in Chandil reservoir in Jharkhand, is encouraging [43].

\begin{tabular}{|c|c|c|c|c|c|}
\hline Diseases & Species affected & Stage of fish & & al distri & \\
\hline \multicolumn{3}{|l|}{ A. Bacterial diseases } & Summer & Rainy & Winter \\
\hline Aeromoniasis & Freshwater fishes & All stages & Yes & Yes & Yes \\
\hline Red disease & Freshwater fishes & Grow out and Adult & Yes & Yes & Yes \\
\hline Edwardsellosis & $\begin{array}{l}\begin{array}{l}\text { All freshwater and some brackish water } \\
\text { fishes }\end{array}\end{array}$ & Mostly fry and fingerlings & No & Yes & Yes \\
\hline Bacterial gill disease & All freshwater fishes & Grow out and Adult & No & No & Yes \\
\hline Columnaris disease & All freshwater fishes & All stages & Yes & No & No \\
\hline Vibriosis & Freshwater prawn and shrimps & All stages & Yes & Yes & No \\
\hline \multicolumn{6}{|l|}{ B. Viral diseases } \\
\hline Whites pot disease & Penaeus monodon, P. vennamei & All stages & Yes & Yes & Yes \\
\hline White tail disease & Macrobrachium rosenbergii & Post larvae and juvenile & Yes & Yes & Yes \\
\hline \multicolumn{6}{|l|}{ C. Fungal diseases } \\
\hline Saprolegniasis & All freshwater fishes & All stages & No & No & Yes \\
\hline \multicolumn{6}{|l|}{ D. Parasitic diseases } \\
\hline Argulosis & $\begin{array}{l}\text { All freshwater fishes with scales are } \\
\text { affected. Labeo rohita more susceptible }\end{array}$ & Adult & No & Yes & Yes \\
\hline Lernaeasis & All freshwater fishes & Adult and Juveniles & No & Yes & Yes \\
\hline Myxosporidiasis & All freshwater fishes & All stages & Yes & Yes & Yes \\
\hline Dactylogyrosis & All freshwater fishes & Adult & No & Yes & Yes \\
\hline
\end{tabular}

Table 4: Seasonal variation of disease occurrence in Indian aquaculture. 
However, some important aspects which needs urgent attention for enhancement in fish production include stocking of right mix of fast growing fish varieties, specifically the improved disease resistance variety of IMC, easy availability of quality fish seed, implementation of scientific culture practices in community ponds or tanks. Again, anthropogenic activities leading to decrease water flow, loss of habitat and above all discharge of sewage and toxic factory effluents, polluting large sections of water bodies, coupled with indiscriminate fishing pressure have deeply impacted fish production from water bodies. Development of suitable preventive and control measures, specifically therapy for fish diseases assumes paramount significance, for the farmers to protect their crop against pathogens. Besides implementation of Better Management Practices (BMP) is important to prevent frequent occurrence of disease and production loss in aquaculture. Further enhancement in knowledge about the disease process, hostpathogen and the environment interaction leading to disease occurrence, are very much essential for development of scientific methods of disease control programme [21]. A good understanding of disease prevalence status, indigenous technologies for disease prevention and control, development suitable economic bio security programme and implementing farm-level BMPs and husbandry measures are key components, which must be given due attention for sustainable fisheries production in the region.

\section{Acknowledgment}

All the authors are grateful to Director ICAR-CIFA for all kind of necessary support to carry out the work. The cooperation and help provided by all State Fisheries Department for providing necessary information, is also acknowledged. Authors are also thankful to ICAR for financial support in form of "ICAR-All India Network Project on Fish Health".

\section{References}

1. Tripathi SD (2012) Need for diversification of species and systems as resource-based, region-specific freshwater aquaculture. In: Swain SK, Swain P, Pillai BR, Raghunath MR, Jayasankar P (eds.). Lead papers on strategies for Aquaculture Development. ICAR-Central Institute of Freshwater Aquaculture. Bhubaneswar, India.

2. DADF (2016) Guidelines - Central Sector Scheme on Blue Revolution: Integrated Development and Management of Fisheries. Department of Animal Husbandry, Dairying \& Fisheries, Ministry of Agriculture and Farmers Welfare, Government of India, India.

3. FAO (2014) Opportunities and challenges. The State of World Fisheries and Aquaculture. Food and Agriculture Organization of the United Nations, Rome, Italy.

4. FAO (2016) National Aquaculture Sector Overview, Fisheries and Aquaculture Department, Food and Agriculture Organization of the United Nations for a world without hunger, India.

5. Jelte de Jong (2017) Aquaculture in India, Rijksdienst voor Ondernemend Nederland.

6. Anon (2017) Aquaculture Production in India.

7. Bondad-Reantaso MG, Subasinghe RP, Arthur JR, Ogawa K, Chinabut S, et al. (2005) Disease and health management in Asian aquaculture. Vet Parasitol 132: 249-272.

8. Goswami C, Zade VS (2015) Statistical Analysis of Fish Production in India. International Journal of Innovative Research in Science, Engineering and Technology 4: 294-299.

9. Press Information Bureau (2017) Blue Revolution, Ministry of Agriculture, Government of India, India.
10. Kumar Prem, Khar Sanjay, Dwivedi Sudhakar, Sharma Shiv Kumar et al. (2015) An Overview of Fisheries and Aquaculture in India. Agro Economist 2: 1-6.

11. Walker PJ, Winton JR (2010) Emerging viral diseases of fish and shrimp. Vet Res 41: 51

12. Ahmed K, Kumar WAG (2005) Handbook on Fish and crustacean diseases in the SAARC region. ( $1^{\text {st }}$ edn), SAARC Agricultural Information Centre, Bangladesh.

13. Suresh VR (2017) Sustainable Fisheries and Aquaculture. In: souvenir of National Seminar on Priorities in fisheries and aquaculture (ed.). ICAR-Central Inland Fisheries Research Institute, Barrackpore, India.

14. Katiha Pradeep K, Jena JK, Pillai NGK, Chakraborty Chinmoy, Dey MM (2005) lnland Aquaculture in India: Past Trend, Present Status and Future Prospects, Aquaculture Economics \& Management 9: 237-264.

15. Ayyappan S (2004) Enhancing global competition. Survey of Indian Agriculture. The Hindu 97-100.

16. Katiha PK (2000) Freshwater aquaculture in India: Status, potential and constraints. Proceedings of the Aquaculture Development in India: Problems and Prospects Workshop. In: Krishnan M, Birthal PS (eds.). National Centre for Agricultural Economics and Policy Research, New Delhi, India.

17. Siddick SA, Durairaja R, Oliverking EdI (2014) Freshwater Fish Culture in Agro-biodiversity Hot spots, Community Initiative in India. Presented in International Food Security Dialogue: Enhancing Food Production, Gender Equity and Nutritional Security in a Changing World.

18. Bagum N, Monir MS, Khan MH (2013) Present status of fish diseases and economic losses due to incidence of disease in rural freshwater aquaculture of Bangladesh. J Innov Dev Strategy 7: 48-53.

19. Mohan CV, Bhatta R (2002) Social and economic impacts of aquatic animal health problems on aquaculture in India. In: Arthur JR, Phillips MJ, Subasinghe RP, Reantaso MB, Mac Rae (eds.). Primary Aquatic Animal Health Care in Rural, Small-Scale, Aquaculture Development. Food and Agriculture Organization of the United Nations, Rome, Italy.

20. Sahoo PK, Mohanty J, Garnayak JSK, Mohanty BR, Kar Banya (2013) Estimation of loss due to argulosis in carp culture ponds in India. Indian J Fish 60: 99-102.

21. Subasinghe RP, Bondad-Reantaso MG, McGladdery SE (2001) Aquaculture development, health and wealth. In: Subasinghe RP, Reantaso MGB, McGladdery SE (eds.). Aquaculture in the Third Millennium. Technical Proceedings of the Conference on Aquaculture in the Third Millennium, Bangkok, Aquaculture in the Third Millennium, Bangkok, Thailand. Pg no: $167-1914$.

22. Das BK, Mishra SS (2014) Diseases in Freshwater aquaculture, In: Training Manual on Model training course on Preventive health management practices in freshwater aquaculture. ICAR-Central Institute of Freshwater aquaculture, Bhubaneswar, Odisha, India.

23. Briggs M, Funge-Smith S, Subasinghe R, Phillips M (2004) Introductions and movement of Penaeus vannamei and Penaeus stylirostris into Asia and the Pacific. Food and Agriculture Organization of the United Nations, Regional Office for Asia and the Pacific. Regional Office for Asia and the Pacific, Bangkok, Thailand.

24. Snieszko SF (1974) The effects of environmental stress on the outbreaks of infectious diseases of fish. Journal of Fish Biology 6: 197-208.

25. Vijayan KK, Sanil NK (2012) Health Management Strategies for profitable and sustainable Aquaculture, with special reference to diagnostics. In: Swain SK, Swain P, Pillai BR, Raghunath MR Jayasankar P (eds.). Lead papers on strategies for Aquaculture Development. ICAR-Central Institute of Freshwater Aquaculture, Bhubaneswar, India.

26. Mishra SS, Dhiman M, Swain P, Das BK (2015) Fish diseases and health management issues in aquaculture. ICAR-CIFA Training manual No.18, Central Institute of Freshwater Aquaculture, Bhubaneswar, India. 
27. Shaoqi Li (1989) Main fish diseases and their control. In: Integrated Fish Farming in China (ed.). NACA Technical Manual 7. A World Food Day Publication of the Network of Aquaculture Centres in Asia and the Pacific, Bangkok, Thailand.

28. Sahoo PK, Pradhan PK, Sundaray JK, Lal KK, Swaminathan TR (2017) Present Status of freshwater fish and shellfish diseases in India. In : Proceedings of International Symposium on aquatic Animal Health and Epidemiology for sustainable Asian Aquaculture. ICAR-National Bureau of Fish Genetic Resources, Lucknow, India.

29. Sandeep P, Chamundeswari Devi B, Kumar KP (2016) Present status of Parasitic and Bacterial diseases in Fresh Water Fish Seed Farms in East Godavari District, Andhra Pradesh. International Journal of Applied and Pure Science and Agriculture 2: 117-121.

30. Mukherjee SC (2002) Fish diseases in India, their causes and control measures - Winter school on recent advances in diagnosis and management of diseases in mariculture, $7^{\text {th }}$ to $27^{\text {th }}$ November 2002, Course Manual. Central Marine Fisheries Research Institute, Cochin, India.

31. Mohanty BR, Sahoo PK (2007) Edwardsiellosis in fish: a brief review. J Biosci 32: 1331-1344.

32. Das BK (2011) Bacterial Diseases of fish. In: Fish Health management, National Training Programme. Central Institute of Freshwater Aquaculture, Bhubaneswar, India.

33. Farhaduzzaman AM, Alam MM, Hossain M, Hussain MA, Rahman MH (2010) Prevalence of Parasites in the Indian Major Carp, Labeo rohita (Hamilton) in Rajshahi, Bangladesh. 28: 65-68.

34. Monir Md, Shirajum, Bagum N, Rahman S, Ashaf-Ud-Doulah Mohammad, Bhadra A, et al. (2015) Parasitic diseases and estimation of loss due to infestation of parasites in Indian major carp culture ponds in Bangladesh. International Journal of Fisheries and Aquatic Studies 2: 118-122.
35. Walker PD, Flik G, Wendelaar Bonga SE (2004) The biology of parasites from the genus Argulus and a review of the interactions with its host. In: Wiegertjes GF, FlikG (eds.). Host-parasite interactions Garland, Abingdon, UK. Pg no: 107-129.

36. Mishra SS, Dhiman M, Saha M (2010) Fish Disease management in integrated farming systems. Webmed Central 1: 1-12.

37. Mishra SS, Das R, Das BK, Choudhary P, Rathore R, et al. (2017) Status of Aqua-medicines, Drugs and Chemicals Use in India: A Survey Report. J Aquac Fisheries.

38. Anon (2017) Cifax Fish Medicine, Agrawal Trading Company, Raipur, Chhattisgarh, India.

39. Swaminathan TR, Kumar R, Dharmaratnam A, Basheer VS, Sood N (2016) Emergence of carp edema virus in cultured ornamental koi carp, Cyprinus carpio koi, in India, J Gen Virol 97: 3392-3399.

40. Rajendran KV (2017) Health Management and Biosecrity in shrimp aquaculture in India- a review. In: Proceedings of International Symposium on aquatic Animal Health and Epidemiology for sustainable Asian Aquaculture. ICAR-National Bureau of Fish Genetic Resources, Lucknow, India.

41. NACA (2013) National aquatic animal disease surveillance programme launched in India. NACA, Bangkok, Thailand.

42. CIBA (2015) Launch of All India Network Project on Fish Health. CIBA, Tamil Nadu, India.

43. Purohit M (2014) Their land lost to a dam, 2,000 farmers take to fishing - in cages. India Water portal, India. 